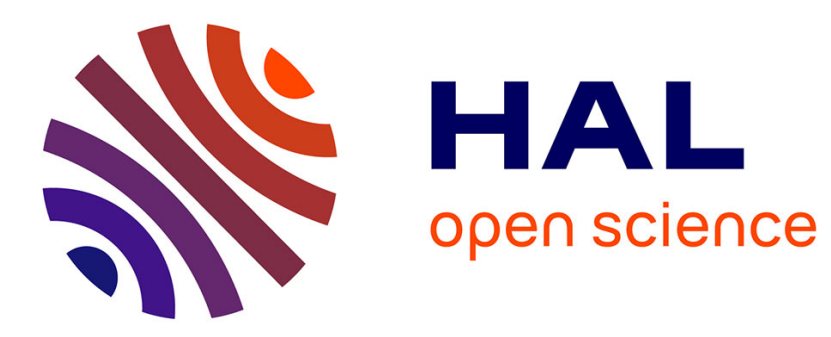

\title{
Links between root developmental traits and foraging performance
}

\author{
Loic L. Pagès
}

\section{To cite this version:}

Loic L. Pagès. Links between root developmental traits and foraging performance. Plant, Cell and Environment, 2011, 34 (10), pp.1749-1760. 10.1111/j.1365-3040.2011.02371.x . hal-02647145

\section{HAL Id: hal-02647145 \\ https://hal.inrae.fr/hal-02647145}

Submitted on 29 May 2020

HAL is a multi-disciplinary open access archive for the deposit and dissemination of scientific research documents, whether they are published or not. The documents may come from teaching and research institutions in France or abroad, or from public or private research centers.
L'archive ouverte pluridisciplinaire HAL, est destinée au dépôt et à la diffusion de documents scientifiques de niveau recherche, publiés ou non, émanant des établissements d'enseignement et de recherche français ou étrangers, des laboratoires publics ou privés.

\section{다)(1) $(5$}

Distributed under a Creative Commons Attribution - NonCommercial| 4.0 International 
Version définitive du manuscrit publié dans / Final version of the manuscript published in : Plant, Cell \& Environment, 2011 , In Press, DOI: 10.1111/j.1365-3040.2011.02371.x

1

Links between root developmental traits and foraging performance

2

Loïc Pagès

3

INRA, UR 1115 Plantes et Systèmes de Culture Horticole

4

5

6

7

8

9

10

Centre d'Avignon, Site Agroparc, 84914 Avignon cedex 9, France

Email : Loic.Pages@avignon.inra.fr

Tel : (33) 432722474

Fax : (33) 432722432

\section{Summary} parameter. Several parameter combinations could lead to similar efficiency gains.

\section{Introduction}

We designed a simple dynamic and stochastic architectural model with six parameters to link the foraging performance of root systems to their developmental processes. Soil foraging was quantified by the volume enveloping the roots until a given uptake distance. Many simulated architectures were obtained by combining four different values for each

The rate of soil colonization was mainly defined by individual root elongation rates and interbranch distances. Less intuitively, we showed that differentiation of elongation rates among the roots increased this colonization rate. Uptake efficiency - the ratio of the actual colonized volume to the volume of a unique cylinder with the same length and a radius corresponding to the uptake distance- declined with root system size. Nevertheless, large variations in efficiency existed among root systems for a given size, typically in a 4 to 10 -fold range. Therefore, the "efficiency gain" was defined as the deviation from the average trend in efficiency versus size. Between-root differentiation in elongation rates increased this gain. The level of hierarchy between mother and lateral roots as well as the variation of elongation rates among lateral roots were also shown to contribute to this optimization.

Key words: Root uptake; Root system architecture; Virtual plants; Water and nutrients; 


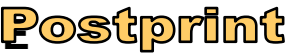

Version définitive du manuscrit publié dans / Final version of the manuscript published in : Plant, Cell \& Environment, 2011 , In Press, DOI: 10.1111/j.1365-3040.2011.02371.x

Water and nutrient uptake is a major function carried out by plant root systems. The development and specialization of root systems allowed plants to colonize many environments in which water and nutrient resources can be scarce and variable in space and time.

At the plant and population levels, this uptake function is affected by both the uptake capacity of individual roots or root parts and by the entire root system architecture (structure and shape) including its dynamics (Lynch, 2007).

The relationship between the architecture and the uptake capacity of root systems has often been considered from a spatial point of view using a number of criteria focusing on the root system shape, particularly extension and distribution. Thus, root depth and root length density distribution are the most common descriptors used as inputs to quantify water and nutrient uptake in crop models (Asseng et al., 1997). Predicting uptake from the spatial distribution of roots relies on the implicit assumption that transport from the soil to the root is the bottleneck in the whole uptake process. Even though one can assume this shortcut in many situations, especially when soil resources are scarce, the quantification of the colonized soil volume and the root length density distribution raises questions. Root length density is generally estimated through measurements on soil samples at a given scale (typically decimeter scale), and is extrapolated at other scales -particularly smaller scales (some millimeters)- for predicting uptake of resources with a low or intermediate mobility (Barber, 1995). Moreover, since observation methods do not preserve the spatial structure of root networks in the soil, we tend to have a biased vision of the actual root distribution and even to ignore it.

Another view on the relationships between root system architecture and uptake capacity was developed by Fitter et al. (2D approach by Fitter, 1987; 3D approach by Fitter et al., 1991) and Berntson (1994). In these approaches, not only was the spatial distribution of roots considered, but also the topological characteristics of root systems. The root system was considered as a binary tree with nodes (branching points) and links (root segments connecting the nodes or apices). These trees were characterized by topological indexes to quantify their overall size and the hierarchy between mother and lateral roots, with two extreme branching patterns (herringbone and dichotomous tree). In addition to topology, metric characteristics were given through internode lengths and branching angles. These studies showed that the foraging efficiency of root systems depends on their topological 
Version définitive du manuscrit publié dans / Final version of the manuscript published in : Plant, Cell \& Environment, 2011 , In Press, DOI: 10.1111/j.1365-3040.2011.02371.x

characteristics: herringbone systems are more efficient at colonizing the soil and capturing nutrients but more expensive and less efficient at transporting these nutrients to the shoot system. Some experimental data validated the hypothesis that one or the other system (herringbone or dichotomous) could be favored by some plastic plant species, which, depending on the resource availability in the soil medium, tended to fit the root system to the situation (Fitter, 1986). Berntson (1994) underlined the necessary trade-off between two antagonistic properties: uptake potential (related to root system size) on the one hand, and uptake efficiency on the other hand. By studying the carbon cost variation of individual root pieces associated with growth and maintenance, Nielsen et al. (1994) advocated the use of architectural models for integrating cost and benefit aspects at the root system level, and made some illustrative calculations. Beyond their specific results, all these studies demonstrated that an important characteristic of roots is that they are linked in a structured branching system and that it is important to consider this in models. In addition, Grabarnik et al. (1998) pointed out that the spatial aggregation of individual roots is a direct consequence of the branching pattern of root systems.

In order to build a more dynamic and developmental point of view, it is worth starting from the elementary building processes which make sense for those who study root development, give constraints to the spatial structure of root systems and contribute to their originality. For example, it is rather trivial to assert that root system extension proceeds at precise locations -near the apex of existing roots- and exhibits local variations which are dependent on the apical characteristics of these roots (e. g. size and age of their meristem). Therefore, the elongation process induces, at a given time, a spatial distribution of new root pieces which is far from random. Likewise, branching is also an important and highly organized process which results in the generation of new lateral meristems at specific locations along their mother roots. Variations in their growth potential and orientation will have further consequences. Therefore, it is clear that elementary developmental processes have an impact on root distribution and dynamics, but their relationships with the integrated performance of root systems are not straightforward. We need tools like simulation models to bridge the different scales and viewpoints. Making these connections is also an important challenge to link studies on the genetic and environmental control of developmental figures made at the root level with studies on integrated functioning at the plant and population level (de Dorlodot et al., 2007). It should also help in the search for relevant developmental 
Version définitive du manuscrit publié dans / Final version of the manuscript published in : Plant, Cell \& Environment, 2011 , In Press, DOI: 10.1111/j.1365-3040.2011.02371.x

153 $D_{\mathrm{I}}=\mathrm{D}_{\mathrm{m}} * M R D B * \exp (V * \Re) / \exp (V)$
154

155

156

157

158

159

160

161

162

163

$\mathfrak{R}$ is a random number from a uniform distribution between 0 and 1 . Parameter MRDB represents the maximal diameter of the branch root relatively to its mother. Values for MRDB were obtained from the compilation of Lecompte et al. (2005) and from Pagès and Serra (1994). Parameter $V$ modulates the variance of the distribution. Examples are given in Figure 1 to illustrate the effect of these parameters on the branching pattern.

Parameter names, abbreviations and values are presented in table 1.

\section{Foraging criteria: definition and calculation}

Like root system development, we modeled soil colonization in a very simple way.

We calculated the soil volumes enveloping the root system at three different distances $\left(d_{1}=3 \mathrm{~mm} ; d_{2}=12 \mathrm{~mm} ; d_{3}=50 \mathrm{~mm}\right.$ ). This enveloping volume is a rough representation of the rhizospheric soil volume that is exploitable by the root system during its development, as suggested by Ge et al. (2000) or Hinsinger et al. (2005). The closest volume (closer than $d_{1}$ ) was assumed to be correlated with the amount of poorly-mobile resources, like phosphate, that can hardly diffuse on some millimeters whilst the distant volume (within $d_{3}$ ) was assumed to be correlated with the amount of mobile resources (like nitrate or water) that can move on several centimeters (Barber, 1995). The intermediate volume (within $d_{2}$ ) is devoted to resources with an intermediate mobility (like potassium).

These volumes were estimated numerically. The soil volume was divided into conveniently sized voxels (typically 4 to $20 \mathrm{~mm}$ in order to obtain a correct accuracy). We calculated the minimal distance from the center of each voxel to the root system. When this distance was smaller than one of the threshold distances, the voxel was considered to be inside the corresponding volume. The product of the number of voxels by the volume of voxels gave an estimate of the enveloping volume. This calculation algorithm allowed us to take overlaps between the rhizospheres of individual root into account.

Time dependent variations in these volumes were considered by repeating the calculations for each time step. 


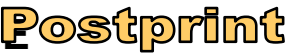

Version définitive du manuscrit publié dans / Final version of the manuscript published in : Plant, Cell \& Environment, 2011 , In Press, DOI: 10.1111/j.1365-3040.2011.02371.x

181

182

183

The accuracy of the volume estimation was tested and it was shown to depend both on the root system size and the voxel size. From simulations, we showed that a voxel size of $5 \mathrm{~mm}$ was satisfactory for obtaining an error below $10 \%$ for the $d_{1}$ volumes, at least for root systems with a total length greater than $80 \mathrm{~cm}$. This error decreased very quickly for longer root systems and was lower for $d_{2}$ and $d_{3}$ volumes (data not shown).

In order to compare the foraging performance of root systems, we defined "efficiency" as the ratio of the colonized volume to the volume of a virtual cylinder with the same length as the whole root system and a radius equal to the considered threshold distance $\left(d_{1}, d_{2}, d_{3}\right)$. This was given by the following equation:

$e=E V /\left(\pi * T L * d_{i}^{2}\right)$

where e is the efficiency, EV the estimated $d_{i}$ volume and $T L$ is the total length of the root system.

\section{Data analysis}

Basically, our strategy was to study the relationships between the six developmental parameters and the foraging criteria defined previously.

For this purpose, we made a large number of simulations combining different values for each parameter (Table 1), and for each simulated root system, we calculated the foraging criteria (volumes and efficiencies as a function of time, as explained above). We considered four different values for each parameter, giving a total of 4096 (i.e. $4^{6}$ ) different simulations. For each simulation, each parameter was drawn at random around a central value $\mathrm{X}$, in the interval $[X-10 \% ; X+10 \%]$. This choice allowed us to systematically sample a large range for each parameter and avoid the drawback of being restricted to a limited number of prefixed values (Saltelli et al., 2008). Within the dataset, each line represented a simulated root system. Columns were: (i) parameter values; (ii) $d_{1}, d_{2}$ and $d_{3}$ volumes at three dates $(20,40$ and 60 days); (iii) corresponding efficiencies.

For an overall exploration of this large data set, we graphed and smoothed the main trends between parameter values and foraging variables. We also used quantiles to study the envelopes of the scatter plots more specifically. Envelopes were interesting for highlighting 
Version définitive du manuscrit publié dans / Final version of the manuscript published in : Plant, Cell \& Environment, 2011 , In Press, DOI: 10.1111/j.1365-3040.2011.02371.x

210 the potential values that can be obtained with some parameter values. Regressions and 211 correlation analyses were used to test our visual impressions during data exploration.

212 Simulations were made by running a home-made $\mathrm{C}++$ program, and data analyses were 213 carried out with the $R$ free software (R Development Core Team, 2010; http://www.R214 project.org/).

\section{Results}

\section{Colonization dynamics}

Very large variations were observed between the dimensions that were reached by the simulated root systems, as shown in table 2 . The total root length in the longest root system was $12.7 \mathrm{~km}$. The largest volume closer than $50 \mathrm{~mm}$ to the root system reached $2.64 \mathrm{~m}^{3}$. The minimal length values (only some $\mathrm{cm}$ ) were less interesting and probably not very realistic. The minimal values for colonized volumes were obviously very small as well, but these values should be considered with care, since the estimation method is not suitable for obtaining accurate data on such small root systems. Median values showed that the distributions were skew, with many more small than large root systems.

Since potential uptake is first determined by the dynamics of the colonized volumes, we focused further investigations on these variables.

Some of the variations observed for colonized volumes were clearly related to parameter values. Figure 2 illustrates some of the relationships. In the graphs both the individual data 230 points were plotted (one per root system) as well as the trends for the upper envelope, joining the $98 \%$ quantiles for eight classes of parameter values. A more systematic presentation of the linear trends is given in table 3 where correlation tests between the parameter classes and these quantiles are shown.

Table 3 shows that the extreme diameters had a clear influence on the colonization potentials. Both extremes were important for the $d_{1}$ volume, while only the maximal diameter was significant for the $d_{3}$ volume. Overall, the larger the diameter range, the higher the colonization potential. 


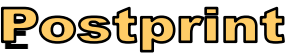

Version définitive du manuscrit publié dans / Final version of the manuscript published in : Plant, Cell \& Environment, 2011 , In Press, DOI: 10.1111/j.1365-3040.2011.02371.x

238

239

240

The slope of growth rate versus diameter was also strongly and positively correlated to the volumes, confirming the importance of plant resource allocation to the roots and differentiation of growth rates (through diameter).

Branching density (inverse of inter-branch distance) also had a clear positive influence on the $d_{1}$ volume, but not on the $d_{3}$ volume where it was counterbalanced by overlapping effects.

Neither the hierarchy between mother and daughter roots nor the variations among daughter roots had a clear effect on the colonized volumes.

\section{Relationship between colonization potential and efficiency}

It is worth noting that the estimated efficiency (from equation 3) was sometimes greater than 1 , especially in the case of very small root systems, because the colonized volume includes both a cylinder volume around the root axis and hemispheric volumes at root ends. It became generally lower than 1 in the case of branched root systems, because of volume overlapping which tended to reduce its value.

As a more general feature, negative correlations between colonization potential and efficiency were systematically observed, as shown in figure 3 for the three distances. Efficiencies tended to decrease with root length, because overlapping increased. As expected, this decreasing trend was more pronounced as the distance increased. These figures revealed that total root length became less and less efficient as the considered distance from the roots increased, and as the root system extended during plant growth. For $2 \mathrm{~km}$ long root systems, the median efficiency values were about $0.67,0.17$ and 0.025 for $d_{1}$, $d_{2}$ and $d_{3}$ respectively, showing the important effect of overlapping.

Nevertheless, there were large variations in efficiency for each size of root system. For example, efficiency varied typically from 0.2 to 1.0 for the $d_{1}$ volume, and relative variations were even higher for larger distances. For $2 \mathrm{~km}$ long root systems, the most efficient ones reached values of approximately 1.0, 0.6 and 0.12 for $d_{1}, d_{2}$ and $d_{3}$ respectively.

Efficiency gain 


\section{P०S\{}

Version définitive du manuscrit publié dans / Final version of the manuscript published in : Plant, Cell \& Environment, 2011 , In Press, DOI: 10.1111/j.1365-3040.2011.02371.x

From these general trends of efficiency versus total length, it was possible to calculate what we can call an "efficiency gain" for each root system as the difference between its observed value and the trend value for the same length. In other words, the "efficiency gain" was a residual from the central trend, used as a measure of the relative performance of each root system in reference to what could be expected, given its size. In the following, the smallest root systems (those under the $10 \%$ length quantile) were discarded because such small root systems were less relevant to our study, and estimates of their efficiency gain could suffer from a lack of accuracy (see material and methods).

The relationship between efficiency gain and age was analyzed by scatter plots (Figure 4) and correlation tests (Table 4) considering values at three dates: 20, 40 and 60 days. Correlations were high, especially between days 40 and 60 and for the biggest distances. The points were distributed around the bisecting line. These results showed that efficiency gains were stable with age, at least after a sufficient growth period. They legitimated our focus on later dates in the following analyses.

Next, efficiency gains (at day 60) were plotted against parameter values together with trend lines (graphs not shown). The correlation coefficients are shown in Table 5. All coefficients were highly significant for the three distances, and there were also significant differences between the considered parameters. In the following, these results are discussed from the highest to the lowest correlations. Inter-branch distance was the most important parameter for the three distances, with its influence increasing with increasing distance. These correlations point out the importance of overlapping between rhizospheres, which increased with branching density. Less intuitive are the positive correlations between efficiency gain and maximal diameter on one hand and efficiency gain and slope of growth rate versus diameter on the other. We interpret these correlations together, because both parameters contribute to increase the between-root differentiation within the root system. Furthermore, both correlations tended to increase with the considered distance (from $d_{1}$ to $d_{3}$ ). A closer examination between maximal diameter and efficiency gain showed that the relationship was not linear: the increase in efficiency gain was more pronounced for diameters between 0.5 and $1.8 \mathrm{~mm}$. The maximal relative diameter of daughter roots correlated negatively with efficiency gain, showing that the hierarchy between mother and daughter roots was an important determinant for efficiency. When lateral roots were given about the same growth potential as their mother roots $(M R D B=0.9)$, the efficiency gain 


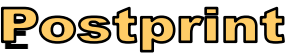

Version définitive du manuscrit publié dans / Final version of the manuscript published in : Plant, Cell \& Environment, 2011 , In Press, DOI: 10.1111/j.1365-3040.2011.02371.x

298

299

300

301

302

303

Differences between distances for the efficiency gains

In order to examine the differential impact of parameters on the efficiency gains for the different distances, we calculated the differences between efficiency gains for the extreme distances $\left(d_{1}\right.$ and $\left.d_{3}\right)$ and explored their relationships with parameter values.

This investigation confirmed some points that we perceived in the previous correlation analysis. Firstly, the growth rate differentiation (through parameters $D_{\max }$ and $E$ ) was much more important for increasing efficiency at large compared to short distance. Secondly, an increase of inter-branch distance above $6 \mathrm{~mm}$ had a higher impact on the efficiency gain observed for large distance.

\section{Root system size and "optimal" parameters}

Since parameter values for the most efficient root systems may depend on their size, we selected the root systems with the highest efficiency gain in each class of root system size, defined by their total length. In order to retain the same number of root systems in each class, we divided the population of root systems using quantiles with class breaks as the quantile values: $0.5,0.6, \ldots, 1.0$. Thus, once again we have excluded the small root systems (under quantile 0.5 ). The most significant results are presented in figure 5. From the trends in figures $5 \mathrm{~A}$ and $5 \mathrm{~B}$ (relative to $d_{1}$ volume) it is clear that maximal diameter was an 
Version définitive du manuscrit publié dans / Final version of the manuscript published in : Plant, Cell \& Environment, 2011 , In Press, DOI: 10.1111/j.1365-3040.2011.02371.x

Interactions between parameters

In addition to these analyses, focused on individual parameters, we studied correlations between parameters among large and efficient root systems, in order to detect possible combined effects for pairs of parameters. For this, only root systems above both the 0.8 quantile for total length and efficiency gain were selected. This generated a sub-population of 162 individuals on which the highly significant correlations $(p<0.001)$ between parameters are reported in table 6 . These correlations were very similar for the three distances $d_{1}, d_{2}$ and $d_{3}$. They reveal that some parameters act in association and highlight possible combined strategies for reaching both high colonization volume and efficiency gain. Thus, the positive correlation between IBD and $R M D B$ showed that the higher the growth rate of laterals, the higher their spacing along the mother root. Complementarily, the negative correlation between $I B D$ and $V$ indicates that small spacing between laterals was associated with high growth rate variations among laterals. The negative correlation between $D_{\max }$ and $R M D B$ reflects that a strong hierarchy between mother and daughter roots (low $R M D B$ ) required thick roots (high $D_{\max }$ ).

Figure 6 illustrates that similar characteristics for total length and efficiency were obtained with different parameter associations. Parameters for these two root systems are shown in table 7. 
Version définitive du manuscrit publié dans / Final version of the manuscript published in : Plant, Cell \& Environment, 2011 , In Press, DOI: 10.1111/j.1365-3040.2011.02371.x

353

\section{Discussion and conclusion}

This in silico study demonstrated the quantitative effects of individual root developmental processes on the global foraging performance of root systems. The models and simulations allowed part of the complexity to be elucidated and provided a general framework for such a study, by taking into account a large part of the diversity of plants and soil resources. The root architecture model that was used was a sort of synthesis or summary of previous models developed over the last 20 years, among which some have been tested in field conditions (Pellerin and Pagès, 1996). The number of parameters (six in this case) was very low in order to allow systematic tests of their effects by crossing their values (Saltelli, 2008). Unlike previous work, we used developmental parameters characterizing different processes instead of morphological (and static) characteristics because we thought that it was important to clearly separate the processes. For example, the length of internal links (or internodes) is the result of both the branching process (with inter-branch distance parameter) and the growth process (selection of growing roots beyond the minimal diameter). On real root systems, it is also modified by root shedding. Several processes were stochastic in this model, such as the emergence direction of lateral roots, their trajectory, and the growth rate of lateral roots. We considered that random aspects of development should be included, since stochasticity can make sense on several aspects of root system functioning and is not the sole result of environmental variations (Forde, 2009). Regarding soil resources, it was assumed that the amount of resources that can be acquired by the plant is, on average, approximately proportional to the soil volume enveloping the roots. The distance from the roots of the volume contour was considered as essentially dependent on the soil-to-root transport capacity of these soil resources. This model was deliberately very simple, because our aim was not to quantify uptake for a given soil, but to compare a large number of architectures under average conditions. Specific cases of soil heterogeneity (far from randomness, or predictable) are beyond the scope of this general approach.

\section{Colonization dynamics}

The first important criterion for evaluating the virtual root systems was their ability to colonize the soil volume as quickly as possible. Berntson (1994) used the term "potential" to qualify this prime characteristic. The dynamics of this potential are obviously important 


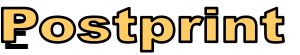

Version définitive du manuscrit publié dans / Final version of the manuscript published in : Plant, Cell \& Environment, 2011 , In Press, DOI: 10.1111/j.1365-3040.2011.02371.x

dependent on the colonized volume that was considered, since overlaps are more frequent and important for large rhizospheres. In our population, it typically decreased down to 0.6 for the small enveloping volume ( $3 \mathrm{~mm}$ distance), and down to 0.02 for the largest $(50 \mathrm{~mm}$ distance).

\section{Efficiency for a given size was highly sensitive to developmental parameters}

Interestingly, we also showed that the size - efficiency relationship was not as tight as assumed by Berntson (1994), and that there was room for root systems to enhance their efficiency regardless of size. Efficiency varied typically in a 4 to 10 -fold range for a given size. This fact led us to study more thoroughly the difference between the expected efficiency (approximated by the average trend) and the "actual" efficiency of each individual root system. This difference, called the "efficiency gain", was a very interesting performance criterion, since it was size independent (by construction) and was shown to be almost age independent.

The differentiation of root growth rate was an important aspect of efficiency gain, on which several parameters contributed (maximal diameter, minimal diameter, slope of elongation rate versus diameter). This differentiation always appeared to favor efficiency gain, especially for the largest enveloping volume, and the largest root systems. This finding may be linked to the important notion of heterorhizy. Instead of developing one single type of roots, with approximately the same morphogenetic potentials, many plant species have evolved developing differentiated roots (Waisel and Eshel, 2002). Thick roots (macrorhizae) extend the external boundaries of the colonized volume, while fine roots (brachyrhizae) can colonize and exploit the intermediate spaces. Nevertheless, root differentiation is constrained by biophysical limitations. The thickest roots $(3.3 \mathrm{~mm}$ in this study) are expensive to build, they have a low surface to mass ratio, and their growth cost is high, especially in strong soils. The majority of soil pores are much smaller than their tip, so to penetrate their environment they must push large volumes of soil. Root fineness is also limited, as discussed by Fitter (1987), by the structural organization of individual roots and their resistance to water transport. Increasing the specific root length by diminishing root diameter is a common response of root systems in the case of nutrient shortage, with an obvious effect on the global carbon cost of the root system (Comas and Eissenstat, 2004; 
Version définitive du manuscrit publié dans / Final version of the manuscript published in : Plant, Cell \& Environment, 2011 , In Press, DOI: 10.1111/j.1365-3040.2011.02371.x

447 Comas and Eissenstat, 2009). However this strategy is likely to reduce diameter 448 differentiation in the whole root system. The lower diameter limit that we used $(0.045 \mathrm{~mm})$ 449 is probably not far from the absolute limit, but it is worth noting that many plants, especially vulnerability to drought or grazing. Root hairs and mycorhizae are probably efficient alternatives for increasing the very local soil-plant exchanges.

Another important characteristic, not unrelated to differentiation, was the hierarchy between mother and daughter roots. This property was quantified using the MRDB parameter. Fitter et al. (1991) found that a pronounced hierarchy between a root and its laterals (herringbone pattern) was favorable for exploration efficiency, in comparison to a dichotomous pattern. Our study confirms this point, and also provides several nuances. It is especially true for the high distance volume, and for low inter-branch distances. When interbranch distance was higher than $10 \mathrm{~mm}$, intermediate and low hierarchies resulted in the best efficiencies.

Interestingly, our study highlights the role of growth rate variation among laterals, qualified as "good noise" by Forde (2009). Efficiency was increased when lateral roots of various growth rates were alternated along the mother root. Among these laterals, the shortest exploit the local space, whilst the longest can deplete farther sites and are complemented by their own laterals. Thus, we confirmed that not only deterministic processes should be considered in such an approach, but also the stochastic ones. It is probable that stochasticity would also improve the global efficiency of a plastic response to heterogeneity. The amplitude of these types of variations and their origin remains to be studied.

The role of inter-branch distance is also decisive for shaping the root system. Typical observed values of inter-branch distance (say from 2 to $10 \mathrm{~mm}$ ) are rather under valued compared to the most efficient found in our study (from 6 to $24 \mathrm{~mm}$ ). We have seen that branching density is central for multiplying the number of growing roots, and is therefore a major factor for speeding up colonization. Meanwhile, we found that it is unfavorable for efficiency gains if the inter-branch distance is lower than the radius of the considered rhizosphere. This can be linked to the interior links as defined by Fitter (1987). Some tradeoff must be found by the growing plant on this adjustment, since several more or less mobile resources must be taken. This trait should be analyzed in relation to the most limiting resources in the plant environment (Lynch, 2007). Moreover, since lateral roots appear 
Version définitive du manuscrit publié dans / Final version of the manuscript published in : Plant, Cell \& Environment, 2011, In Press, DOI: 10.1111/j.1365-3040.2011.02371.x

along defined rows around the mother root, the within row spacing of lateral roots (as defined and studied by Draye, 2002) might be a developmental way for diminishing overlaps. In addition, self-pruning of those small roots, which have exploited the non-mobile resources of the very local environment, could return inter-branch distance to higher values.

\section{Perspectives}

This work is an introduction towards more detailed and realistic models for understanding how developmental processes contribute to shape efficient root systems. To further improve our capacity to simulate realistic root systems, several new approaches could be taken. As a first step additional developmental processes could be included whose importance should not be underestimated: orientation via tropism, production of adventitious roots on shoot axes, decay and reiteration (Vercambre et al., 2003). Another important way forward would be to consider the interactive and dynamic plasticity of the growing roots in response to a heterogeneous and changing environment. Recent progress in modeling could allow this approach to be merged with a more realistic transport and uptake model, as well as a dynamic carbon model, for refining benefit and cost evaluations, and maybe defining idéotypes of root systems.

\section{Acknowledgements}

I would like to thank Guillaume Pagès for his help in designing a suitable algorithm, Mohammed Ould Sidi for offering computing facility, and Pierre Valsesia for his constant help in programming. Thank you also to Jocelyne Kervella for suggestions and Leigh Gebbie for reading and improving my English. This work was supported by the Agropolis foundation in the frame of the Rhizopolis project.

\section{References}

Asseng S, Richter C, Wessolek G , 1997. Modelling root growth of wheat as the linkage between crop and soil. Plant and Soil 190: 267-277 
Version définitive du manuscrit publié dans / Final version of the manuscript published in : Plant, Cell \& Environment, 2011 , In Press, DOI: 10.1111/j.1365-3040.2011.02371.x

507

508

509

Barber SA, 1995. Soil nutrient bioavailability: a mechanistic approach. John Wiley and Sons, New York USA

Berntson GM, 1994. Modelling root architecture - Are there tradeoffs between efficiency and potential of resource acquisition. New Phytologist 127: 483-493

Cahn MD, Zobel RW, Bouldin DR, 1989. Relationship between root elongation rate and diameter and duration of growth of lateral roots of maize. Plant and Soil 119: 271-279

Comas LH, Eissenstat DM 2004. Linking fine root traits to maximum potential growth rate among 11 mature temperate tree species. Functional Ecology 18: 388-397

Comas LH, Eissenstat DM, 2009. Patterns in root trait variation among 25 co-existing North American forest species. New Phytologist 182: 919-928

Coutts MP, 1987. Developmental processes in tree root systems. Canadian Journal of Forest Research 17: 761-767

Dorlodot S De, Forster B, Pagès L, Price A, Tuberosa R, Draye X, 2007. Root system architecture: opportunities and constraints for genetic improvement of crops. Trends in Plant Science 12: 474-482

Draye $X, 2002$. Consequences of root growth kinetics and vascular structure on the distribution of lateral roots. Plant Cell and Environment 25: 1463-1474

Fitter $\mathrm{AH}, 1986$. The topology and geometry of plant root systems: influence of watering rate on root system topology in Trifolium pratense. Annals of Botany 57: 91-101

Fitter $\mathbf{A H}, 1987$. An architectural approach to the comparative ecology of plant root systems. New Phytologist 106: 61-77

Fitter A.H., 2002. Characteristics and functions of root systems. In Plant roots, the hidden half. Eds. Y Waisel, A Eshel and U Kafkafi. pp 15-32. Marcel Dekker Inc., New-York.

Fitter AH, Stickland TR, Harvey ML, Wilson GW, 1991. Architectural analysis of plant root systems. 1. Architectural correlates of exploitation efficiency. New Phytologist 118, 375-382

Forde BG, 2009. Is it good noise? The role of developmental instability in the shaping of a root system. Journal of Experimental Botany 60: 3989-4002 
Version définitive du manuscrit publié dans / Final version of the manuscript published in : Plant, Cell \& Environment, 2011 , In Press, DOI: 10.1111/j.1365-3040.2011.02371.x

Ge ZY, Rubio G, Lynch JP, 2000. The importance of root gravitropism for inter-root competition and phosphorus acquisition efficiency: results from a geometric simulation model. Plant and Soil 218: 159-171

Grabarnik P, Pagès L, Bengough AG, 1998. Geometrical properties of simulated maize root systems: consequences for length density and intersection density. Plant and Soil 200: 157-167

Hackett C. 1973. A growth analysis of the young sorghum root system. Australian Journal of Biology Science 26: 1211-1214.

Hinsinger P, Gobran GR, Gregory PJ, Wenzel WW, 2005. Rhizosphere geometry and heterogeneity arising from root-mediated physical and chemical processes. New Phytologist 168: 293-303

Hummel I, Vile D, Violle C, Devaux J, Ricci B, Blanchard A, Garnier E, Roumet C, 2007. Relating root structure and anatomy to whole-plant functioning in 14 herbaceous Mediterranean species. New Phytologist 173: 313-321

Kutschera L, 1960. Wurzelatlas mitteleuropäischer Ackerunkräuter und Kulturpflanzen. DLG-Verlag., Frankfurt am main, Germany.

Lecompte F., Pagès L., Ozier-Lafontaine H., 2005. Patterns of variability in the diameter of lateral roots in the banana tree root system. New Phytologist 167: 841-850

Leitner D, Klepsch S, Bodner G, Schnepf A, 2010. A dynamic root system growth model based on LSystems. Plant and Soil 332: 177-192

Lynch JP, 2007. Roots of the second green revolution. Australian Journal of Botany 55: 493-512

Nielsen KL, Lynch JP, Jablokow AG, Curtis PS, 1994. Carbon cost of root systems - An architectural approach. Plant and Soil 165 : 161-169

Pagès L, 1995. Growth patterns of the lateral roots in young oak (Quercus robur L.) trees. Relationship with apical diameter. New Phytologist 130: 503-509

Pagès L, Aries F, 1988. SARAH : modèle de simulation de la croissance, du développement, et de l'architecture des systèmes racinaires. Agronomie 8: 889-896

Pagès L, Kervella J, Chadoeuf J, 1993. Development of the root system of young peach trees (Prunus persica L. Batsch): a morphometrical analysis. Annals of Botany 71: 369-375

Pagès L, Serra V 1994. Growth and branching of the taproot of young oak trees. A dynamic study. Journal of experimental Botany 45 : 1327-1334 
Version définitive du manuscrit publié dans / Final version of the manuscript published in : Plant, Cell \& Environment, 2011, In Press, DOI: 10.1111/j.1365-3040.2011.02371.x

563 Pagès L, Vercambre G, Drouet J-L, Lecompte F, Collet C, Le Bot J, 2004. RootTyp : a generic model to 564 depict and analyse the root system architecture. Plant and Soil 258: 103-119

565 Pellerin S, Pagès L, 1996. Evaluation in field conditions of a three-dimensional architectural model of the maize root system: comparison of simulated and observed horizontal root maps. Plant Soil 178:

$567 \quad 101-112$

Ryser P, 2006. The mysterious root length. Plant and Soil 286: 1-6

569 Roumet C, Lafont F, Sari M, Warembourg F, Garnier E, 2008. Root traits and taxonomic affiliation of nine herbaceous species grown in glasshouse conditions. Plant and Soil 312: 69-83

R Development Core Team, 2010. R: A language and environment for statistical computing. R Foundation for Statistical Computing, Vienna, Austria. ISBN 3-900051-07-0, URL http://www.Rproject.org/.

Saltelli A, Ratto M, Andres T, Campolongo F, Saisana M, Tarantola S 2008. Global sensitivity 575 analysis. The primer. John Wiley \& Sons Ltd. 292 p.

Vercambre G, Pagès L, Doussan C, Habib R, 2003. Architectural analysis and synthesis of the plum tree root system in an orchard using a quantitative modelling approach. Plant and Soil 51: 1-11

Waisel Y, Eshel A, 2002. Functional diversity of various constituents of a single root system. In Plant roots, the hidden half. Eds. Y Waisel, A Eshel and U Kafkafi. pp 157-174. Marcel Dekker Inc., New580 York.

581 Wilcox H, 1962. Growth studies of the root of incense cedar, librocedrus decurrens ii. morphological features of the growth system and root behaviour. American Journal of Botany 49: 237-245 


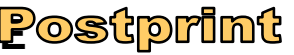

Version définitive du manuscrit publié dans / Final version of the manuscript published in : Plant, Cell \& Environment, 2011 , In Press, DOI: 10.1111/j.1365-3040.2011.02371.x

584 Table 1: Names, units and central values of model parameters. For each simulation, a par585 ticular value was drawn at random uniformly in the interval $[X-10 \% ; X+10 \%]$, where $X$ is a 586 central value. All combinations of values were used, giving a total of 4096 simulations (i.e. $4^{6}$ ).

\begin{tabular}{|l|c|c|c|c|}
\hline Parameters & $\mathbf{1}$ & $\mathbf{2}$ & $\mathbf{3}$ & $\mathbf{4}$ \\
\hline $\begin{array}{l}\text { Minimal diameter } \\
D_{\min }(\mathrm{mm})\end{array}$ & 0.05 & 0.10 & 0.20 & 0.30 \\
\hline $\begin{array}{l}\text { Maximal diameter } \\
D_{\max }(\mathrm{mm})\end{array}$ & 0.5 & 1 & 1.8 & 3 \\
\hline $\begin{array}{l}\text { Slope of growth rate versus diameter } \\
E \text { (day }{ }^{-1} \text { ) }\end{array}$ & 8 & 12 & 18 & 28 \\
\hline $\begin{array}{l}\text { Inter-branch distance } \\
\text { IBD (mm) }\end{array}$ & 3 & 6 & 12 & 24 \\
\hline $\begin{array}{l}\text { Maximal relative diameter of branch } \\
\text { root } M R D B(--)\end{array}$ & 0.3 & 0.5 & 0.7 & 0.9 \\
\hline $\begin{array}{l}\text { Variation diameter branch root } \\
V(--)\end{array}$ & 0.5 & 1 & 2 & 3 \\
\hline
\end{tabular}




\section{P०S\{}

Version définitive du manuscrit publié dans / Final version of the manuscript published in : Plant, Cell \& Environment, 2011 , In Press, DOI: 10.1111/j.1365-3040.2011.02371.x

590

\begin{tabular}{|c|c|c|c|}
\hline & Minimum & Median & Maximum \\
\hline Length at day $40(\mathrm{~m})$ & 0.0349 & 4.34 & 1924 \\
\hline Length at day $60(\mathrm{~m})$ & 0.0554 & 14.76 & 12710 \\
\hline $\begin{array}{l}d_{1} \text { volume at day } 40 \\
\left(\mathrm{dm}^{3}\right)\end{array}$ & 0.00 & 0.12 & 35.11 \\
\hline $\begin{array}{l}d_{1} \text { volume at day } 60 \\
\left(\mathrm{dm}^{3}\right)\end{array}$ & 0.00 & 0.41 & 137.0 \\
\hline $\begin{array}{l}d_{2} \text { volume at day } 40 \\
\left(\mathrm{dm}^{3}\right)\end{array}$ & 0.021 & 1.61 & 170.7 \\
\hline $\begin{array}{l}d_{2} \text { volume at day } 60 \\
\left(\mathrm{dm}^{3}\right)\end{array}$ & 0.032 & 5.13 & 654.6 \\
\hline $\begin{array}{l}d_{3} \text { volume at day } 40 \\
\left(\mathrm{dm}^{3}\right)\end{array}$ & 0.791 & 15.51 & 746.9 \\
\hline $\begin{array}{l}d_{3} \text { volume at day } 60 \\
\left(\mathrm{dm}^{3}\right)\end{array}$ & 0.948 & 41.53 & 2638 \\
\hline
\end{tabular}


Version définitive du manuscrit publié dans / Final version of the manuscript published in : Plant, Cell \& Environment, 2011 , In Press, DOI: 10.1111/j.1365-3040.2011.02371.x

595 Table 3. Correlation coefficients between parameters and the 0.98 volume quantile 596 (calculated at day 60). For each parameter, eight classes were defined for which the 0.98 597 quantiles were calculated. Coefficients in bold characters are significant at the $5 \%$ level $(d f=7)$.

\begin{tabular}{|l|c|c|c|c|c|c|}
\hline & $D_{\min }$ & $D_{\max }$ & $E$ & $I B D$ & $M R D B$ & $V$ \\
\hline $\mathrm{d}_{1}$ volume & $\mathbf{- 0 . 9 6 6}$ & $\mathbf{0 . 8 2 5}$ & $\mathbf{0 . 9 9 5}$ & $\mathbf{- 0 . 9 6 4}$ & 0.359 & -0.785 \\
\hline $\mathrm{d}_{2}$ volume & $\mathbf{- 0 . 9 1 9}$ & $\mathbf{0 . 9 5 6}$ & $\mathbf{0 . 9 8 9}$ & $\mathbf{- 0 . 8 7 7}$ & 0.236 & -0.584 \\
\hline $\mathrm{d}_{3}$ volume & -0.663 & $\mathbf{0 . 9 9 3}$ & $\mathbf{0 . 9 9 4}$ & 0.576 & 0.180 & 0.342 \\
\hline
\end{tabular}




\section{P०S\{}

Version définitive du manuscrit publié dans / Final version of the manuscript published in : Plant, Cell \& Environment, 2011 , In Press, DOI: 10.1111/j.1365-3040.2011.02371.x

602 Table 4: Correlation coefficients between efficiency gains at three dates: day 20, 40 and 60.

603 All coefficients were highly significant $(\mathrm{df}=3686)$.

\begin{tabular}{|c|c|c|}
\hline Distance & Dates & Correlation coefficient \\
\hline \multirow{2}{*}{$d_{1}$} & day $20-$ day 40 & 0.671 \\
\cline { 2 - 3 } & day $40-$ day 60 & 0.785 \\
\hline \multirow{2}{*}{$d_{2}$} & day $20-$ day 40 & 0.790 \\
\cline { 2 - 3 } & day $40-$ day 60 & 0.940 \\
\hline \multirow{2}{*}{$d_{3}$} & day $20-$ day 40 & 0.893 \\
\hline & day $40-$ day 60 & 0.969 \\
\hline
\end{tabular}




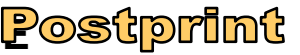

Version définitive du manuscrit publié dans / Final version of the manuscript published in : Plant, Cell \& Environment, 2011 , In Press, DOI: 10.1111/j.1365-3040.2011.02371.x

\begin{tabular}{|l|c|c|c|}
\hline & $\begin{array}{c}\text { Efficiency gain } \\
\text { for distance } d_{1}\end{array}$ & $\begin{array}{c}\text { Efficiency gain } \\
\text { for distance } d_{2}\end{array}$ & $\begin{array}{c}\text { Efficiency gain } \\
\text { for distance } d_{3}\end{array}$ \\
\hline Minimal diameter $\left(D_{\min }\right)$ & 0.0930 & 0.141 & 0.208 \\
\hline Maximal diameter $\left(D_{\max }\right)$ & 0.124 & 0.408 & 0.479 \\
\hline $\begin{array}{l}\text { Slope of growth rate versus } \\
\text { diameter }(E)\end{array}$ & 0.203 & 0.394 & 0.387 \\
\hline $\begin{array}{l}\text { Inter-branch distance }(I B D) \\
\begin{array}{l}\text { Maximal relative diameter of } \\
\text { branch roots }(M R D B)\end{array}\end{array}$ & -0.323 & -0.240 & -0.260 \\
\hline $\begin{array}{l}\text { Variation of diameter of branch } \\
\text { roots }(V)\end{array}$ & 0.242 & 0.253 & 0.309 \\
\hline
\end{tabular}

Table 5: Correlation coefficients between model parameters and efficiency gains for the three distances $d_{1}, d_{2}$ and $d_{3}$. All coefficients were highly significant ( $d f=3686$ ). 
Version définitive du manuscrit publié dans / Final version of the manuscript published in : Plant, Cell \& Environment, 2011 , In Press, DOI: 10.1111/j.1365-3040.2011.02371.x

612 Table 6: Correlation coefficients that were highly significant between parameters among

613 large and efficient root systems. The selection method led to a sub-population of 162 root systems (see the text).

\begin{tabular}{|l|c|c|}
\hline \multicolumn{2}{|l|}{ Correlation coefficients for $\mathbf{d}_{\mathbf{1}}$ volume (df = 161) } \\
\hline & $R M D B$ & $V$ \\
\hline$D_{\max }$ & -0.481 & -0.384 \\
\hline$I B D$ & 0.434 & \\
\hline Correlation coefficients for $\mathbf{d}_{\mathbf{3}}$ volume (df $\left.=\mathbf{1 6 1}\right)$ \\
\hline$D_{\max }$ & -0.317 & \\
\hline$I B D$ & 0.540 & -0.373 \\
\end{tabular}


Press, DOI: 10.1111/j.1365-3040.2011.02371.x

Table 7: Parameter values for the two root systems presented in Figure 6.

619

\begin{tabular}{|c|c|c|}
\hline Parameters & $\begin{array}{l}\text { Root system } \\
\text { Fig } 6 A \text { and } 6 B\end{array}$ & $\begin{array}{l}\text { Root system } \\
\text { Fig } 6 C \text { and } 6 D\end{array}$ \\
\hline $\begin{array}{l}\text { Minimal diameter } \\
D_{\min }(\mathrm{mm})\end{array}$ & 0.203 & 0.188 \\
\hline $\begin{array}{l}\text { Maximal diameter } \\
D_{\max }(\mathrm{mm})\end{array}$ & 2.93 & 3.08 \\
\hline $\begin{array}{l}\text { Slope of growth rate versus diameter } \\
E\left(\text { day }^{-1}\right)\end{array}$ & 26.6 & 25.5 \\
\hline $\begin{array}{l}\text { Inter-branch distance } \\
\text { IBD }(\mathrm{mm})\end{array}$ & 23.5 & 23.8 \\
\hline $\begin{array}{l}\text { Maximal relative diameter branch } \\
\text { root } M R D B(--)\end{array}$ & 0.489 & 0.881 \\
\hline $\begin{array}{l}\text { Variation diameter branch root } \\
V(--)\end{array}$ & 0.528 & 2.95 \\
\hline
\end{tabular}


Version définitive du manuscrit publié dans / Final version of the manuscript published in : Plant, Cell \& Environment, 2011 , In Press, DOI: 10.1111/j.1365-3040.2011.02371.x

\section{Figure captions}

Figure 1: Visual illustration of various branching patters obtained by varying the $R M D B$ and $V$ parameters. $A$ : $R M D B=0.3$ and $V=0.5 ; B: R M D B=0.3$ and $V=3.0 ; C$ : $R M D B=0.9$ and $V=0.5 ; D$ : $R M D B=0.9$ and $V=3.0$.

Figure 2: Scatter plots illustrating some of the relationships between the colonized volume and developmental parameters. Each point represents a simulated root system. The lines connect the 0.98 quantiles calculated on eight different classes of each parameter.

Figure 3: Relationships between root system size (total root length) and efficiency for the three distances $d_{1}, d_{2}$ and $d_{3}$. The lines connect the median values calculated for classes of root system sizes.

Figure 4: Relationships between values of efficiency gain for the $d_{3}$ distance and the three dates: day 20, 40 and 60 . The bisecting lines are shown.

Figure 5: Relationship between parameter values and size for optimal root systems. A and B are for the $d_{1}$ volume, $C$ and $D$ for the $d_{3}$ volume. Symbols represent the average value for the most efficient root systems in each class of total length. Bars represent the standard deviation.

Figure 6: Examples of efficient root systems for mobile resources (distance $d_{3}$ ). A and $C$ are side views, and $B$ and $D$ are top views. These two root systems were the same age (40 days), the same length $(100 \mathrm{~m})$ and were approximately as efficient (0.5). They differ in their RMDB and $V$ values. Length units are meters. Parameter values are given in Table 7. 


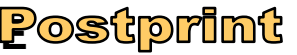

Version définitive du manuscrit publié dans / Final version of the manuscript published in : Plant, Cell \& Environment, 2011 , In Press, DOI: 10.1111/j.1365-3040.2011.02371.x

649

650 Figure 1: Visual illustration of various branching patters obtained by varying the $R M D B$ and $V$ 651 parameters. $A$ : $R M D B=0.3$ and $V=0.5 ; B: R M D B=0.3$ and $V=3.0 ; C: R M D B=0.9$ and $V=0.5 ; D$ : $R M D B=0.9$ and $V=3.0$.

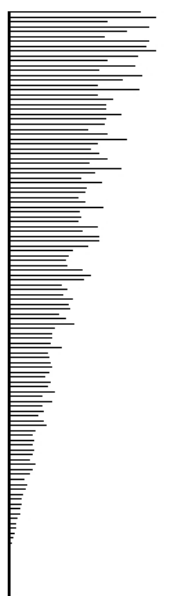

A

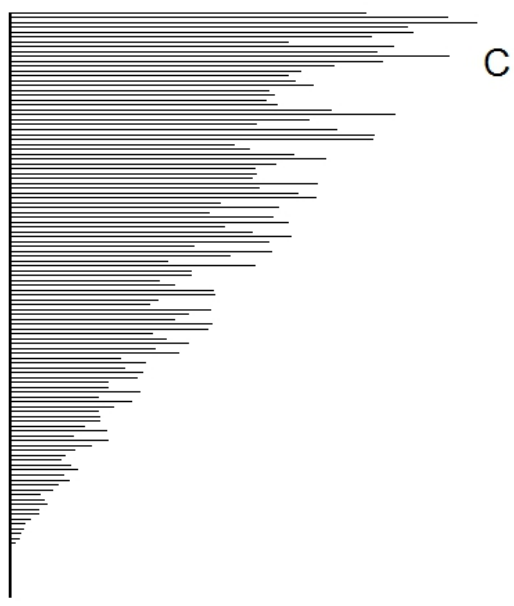

B

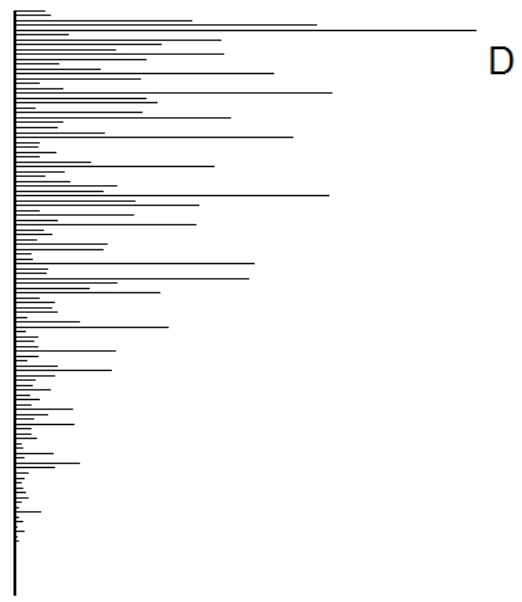




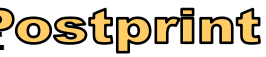

Press, DOl: 10.1111/1365-3040
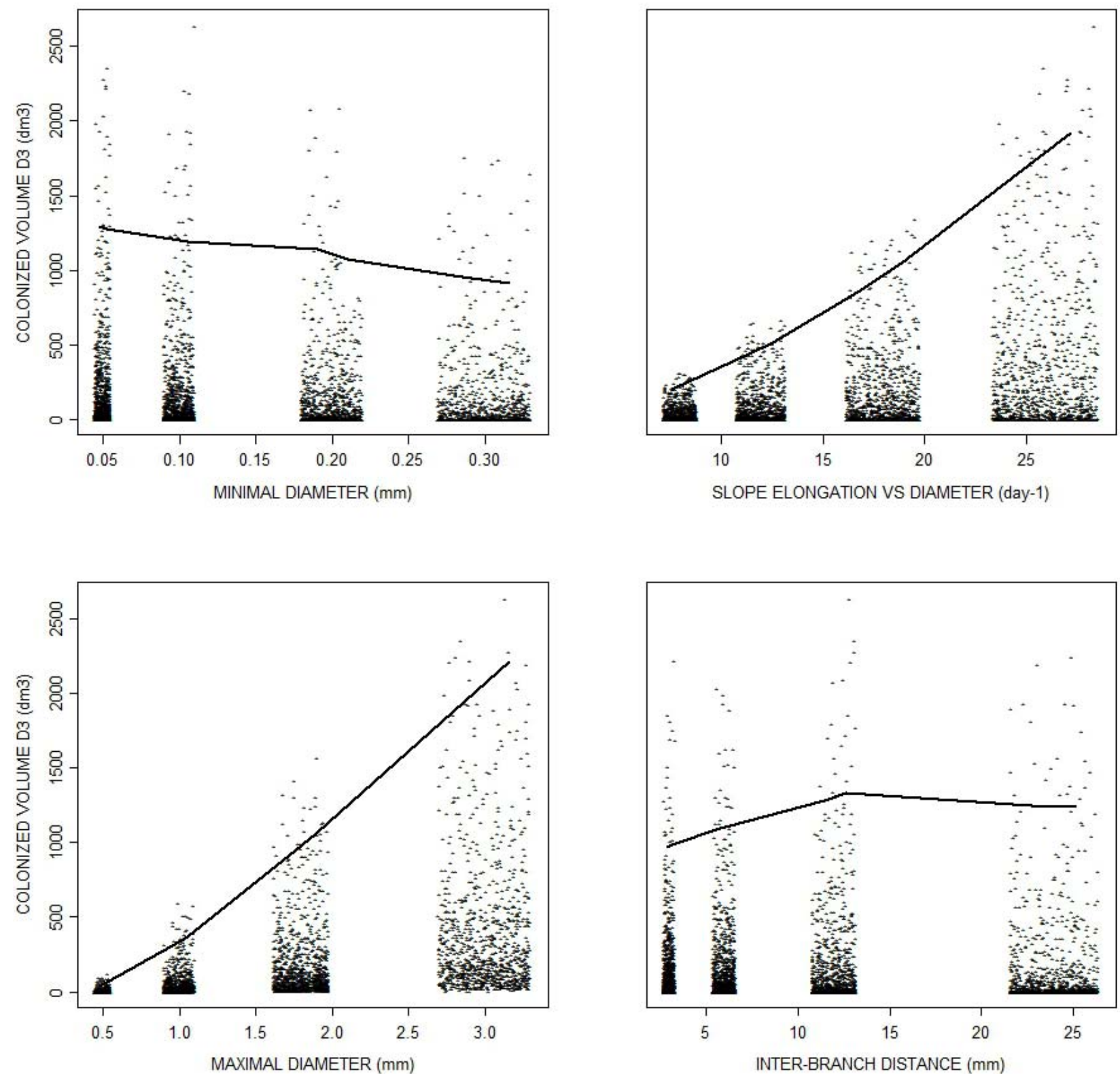


\section{P०S\{}

Version définitive du manuscrit publié dans / Final version of the manuscript published in : Plant, Cell \& Environment, 2011 , In Press, DOI: 10.1111/j.1365-3040.2011.02371.x

Figure 3: Relationships between root system size (total root length) and efficiency for the three distances $d_{1}, d_{2}$ and $d_{3}$. The lines connect the median values calculated for classes of root system sizes.
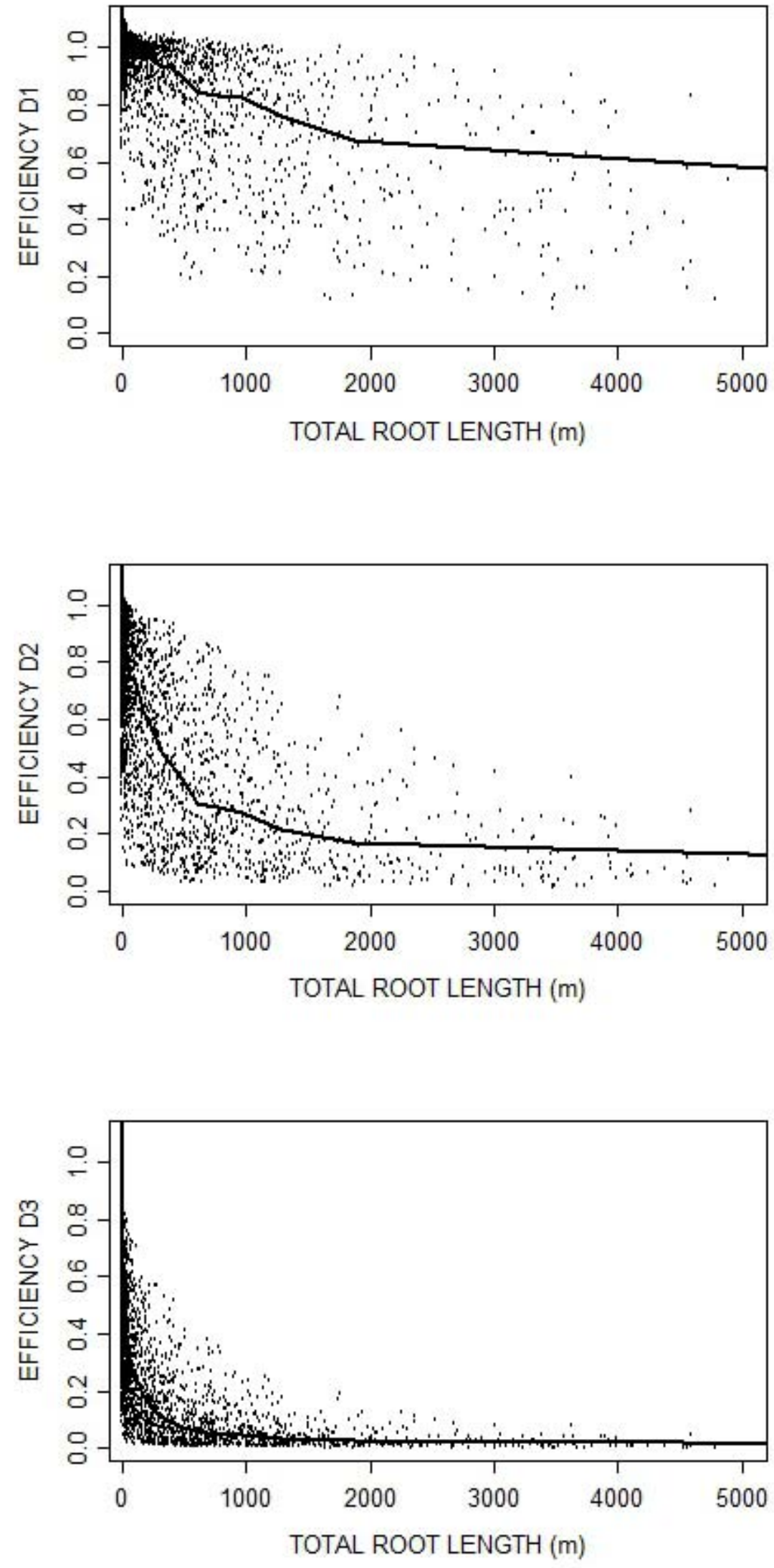


\section{-}

Version définitive du manuscrit publié dans / Final version of the manuscript published in : Plant, Cell \& Environment, 2011, In Press, DOI: 10.1111/j.1365-3040.2011.02371.x

667 Figure 4: Relationships between values of efficiency gain for the $d_{3}$ distance and the three dates: day 20, 40 and 60 . The bisecting lines are shown.
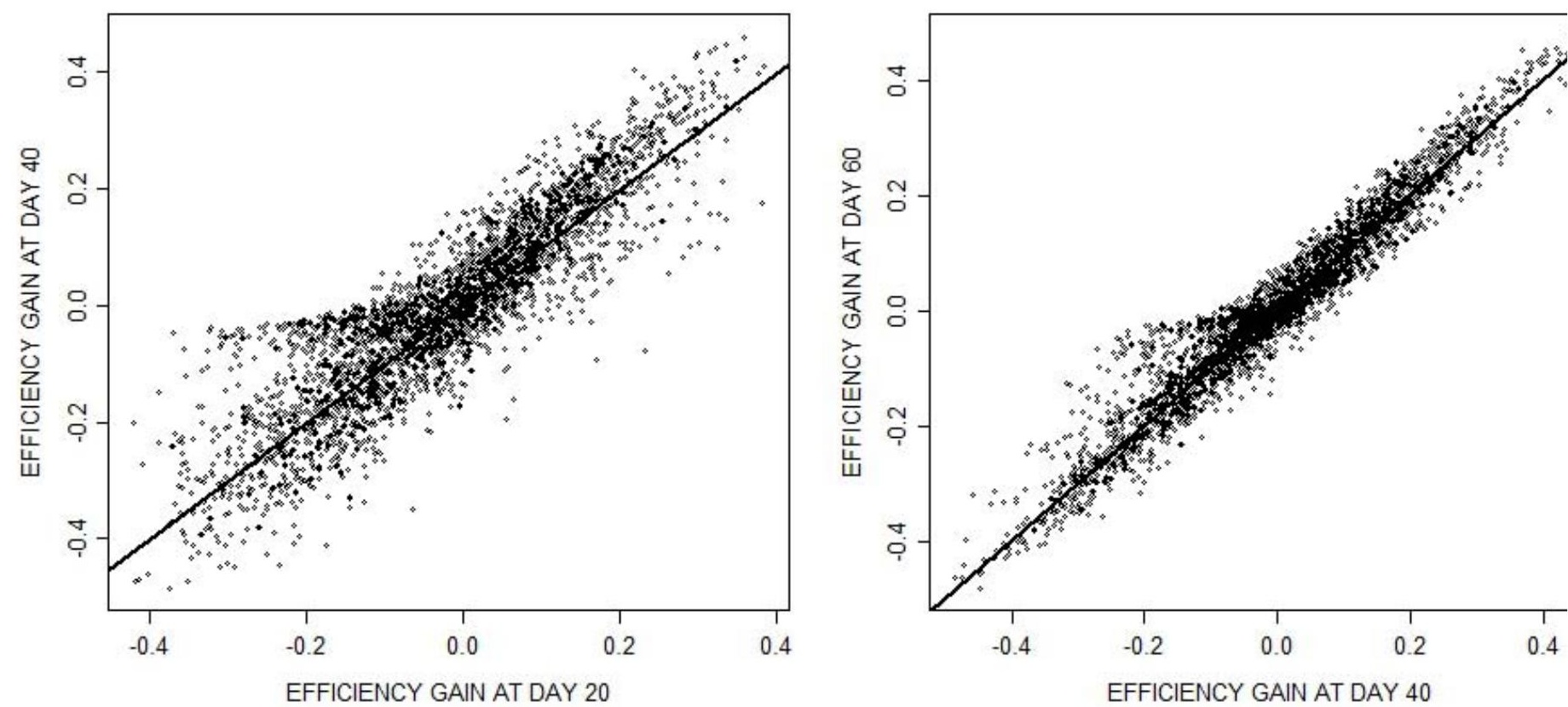


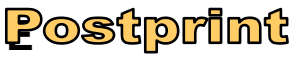

Version définitive du manuscrit publié dans / Final version of the manuscript published in : Plant, Cell \& Environment, 2011 , In Press, DOI: 10.1111/j.1365-3040.2011.02371.x

Figure 5: Relationship between parameter values and size for optimal root systems. A and B

671 are for the $d_{1}$ volume, C and D for the $d_{3}$ volume. Symbols represent the average value for

672 the most efficient root systems in each class of total length. Bars represent the standard dev673 iation.
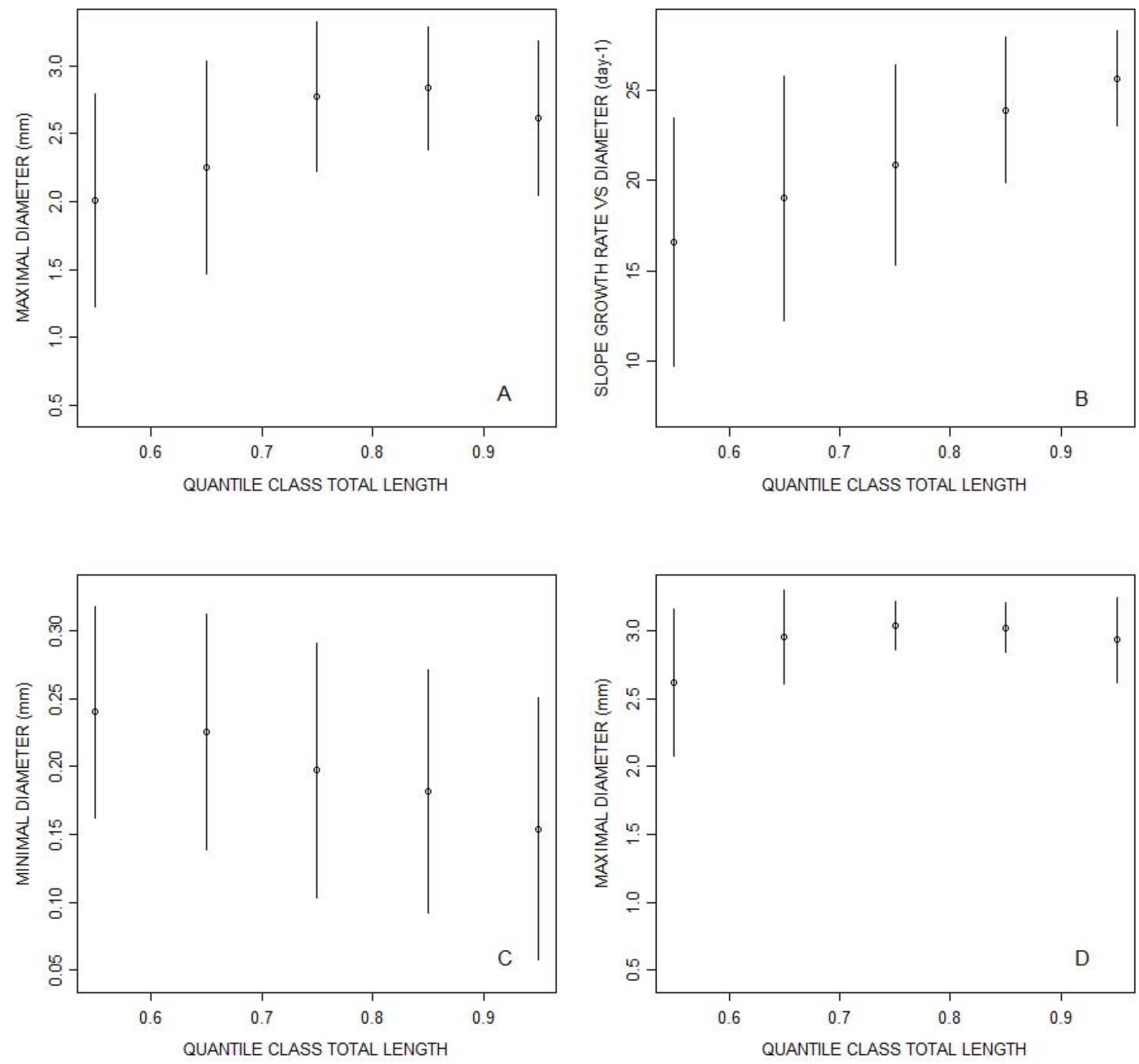


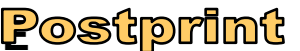

Version définitive du manuscrit publié dans / Final version of the manuscript published in : Plant, Cell \& Environment, 2011 , In Press, DOI: 10.1111/j.1365-3040.2011.02371.x

679 Figure 6: Examples of efficient root systems for mobile resources (distance $d_{3}$ ). A and C are 680 side views, and B and D are top views. These two root systems were the same age (40 days), the same length $(100 \mathrm{~m})$ and were approximately as efficient $(0.5)$. They differ for their $R M D B$ and $V$ values. Length units are meters. Parameter values are given in Table 7.
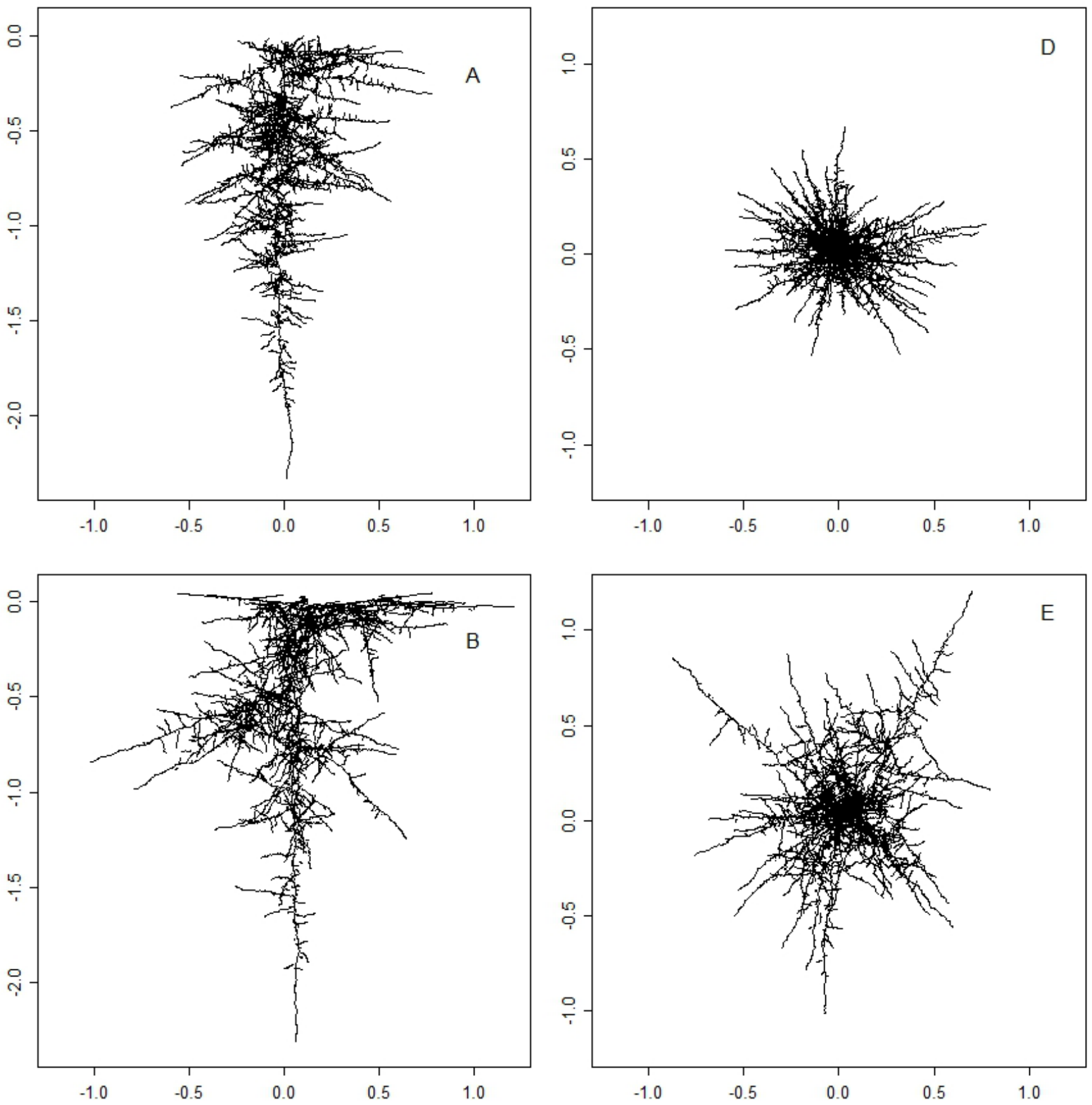